\title{
"The Future of the Research Library" by Fremont Rider: A Reprint of a CERL Classic
}

"As early as 1940, Fremont C. Rider predicted unprecedented growth for American university libraries, based on a nationwide survey of collection data. His subsequent book-length elaboration of these data, which also included a plan for the control of growth, has served since that time as the point of departure for any discussion of collection size, growth, and the many implications of these. In that seminal work, [The Scholar and the Future of the Research Library] Rider examined some of the past efforts to control size, such as weeding and resource sharing, and found them wanting. His recommended solu- tion to the problem rests on a combination of uses of microform. An underlying assumption, however, is that humanists are the primary users of libraries, that their sources are vast, but that a solution to the problems of meeting the humanists' needs would, by and large, also solve the problems of growth and size more generally." -Charles B. Osburn, Academic Research and Library Resources: Changing Patterns in America (Westport, Conn.: Greenwood, 1979), p.92.

"The Future of the Research Library," by Fremont Rider, appeared in College $\mathcal{E}$ Research Library 5:301-8 (Sept. 1944).-Ed. 